\title{
"Pedro, o Múltiplo"
}

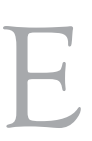

screver sobre o ilustre reumatologista Pedro Nava, cujo centenário de nascimento está sendo comemorado em 2003, é não só um desafio como também um privilégio. Desafio pela multiplicidade de talento desse eclético médico escritor, cuja obra é reverenciada até hoje, e privilégio pela convivência desde o berço, literalmente, em virtude do parentesco e da profissão. É importante que os mais jovens conheçam a sua atuação médica à frente da SBR e também que Pedro Nava foi um dos pioneiros da nossa especialidade e um dos signatários da ata de fundação da SBR. Publicou mais de 300 trabalhos médicos, presidiu congressos, participou de bancas examinadoras, exerceu cátedra e fundou o primeiro serviço público de reumatologia no Brasil, além de ter sido um grande incentivador de leitura e de estudos contumazes. No Congresso Brasileiro de Reumatologia de Recife, em 1970, sob a presidência de Geraldo Gomes de Freitas, promoveu a primeira aula de osteoporose no Brasil ao convidar o professor Stanilas De Sèze para ministrá-la. Por volta de 1953, fez a descrição da "Taquicardia no Lúpus Eritematoso" e a publicou como nota prévia na Revista Brasil-Médico do mesmo ano. Em 1955, publicou na Revista Médico Municipal a descrição da "Doença de Still no Adulto", bem antes de Bywaters em 1974. Descreveu o "Reumatismo Alergobacteriano/Alergotuberculoso", hoje conhecido como artrite reativa e vislumbrou a possibilidade da "Auto-Imunidade da Artrite Reumatóide", também publicada na Revista BrasilMédico em 1959.

No meio literário atuou na Semana de Arte Moderna de 1922, leu exaustivamente Eça de Queiroz, Proust, Baudelaire, Euclides da Cunha, Machado de Assis e Dickens, foi apresentado a Lima Barreto e causou um grande impacto na década de 1940 por ocasião da primeira visita de Pablo Neruda ao Brasil. Ao ser entrevistado ainda no aeroporto, Neruda disse que queria conhecer muito Pedro Nava por causa do poema "O Defunto", escrito em 1938 e considerado pelo poeta chileno como o que havia de melhor no gênero. Carlos Drummond de Andrade o classificou de "Pedro, o Múltiplo": Pedro, o médico; Pedro, o poeta; Pedro, o escritor; Pedro, o pintor; Pedro, o desenhista; Pedro, o crítico literário; Pedro, o ilustrador etc. Sua incomparável obra memorialística foi considerada como a melhor da língua portuguesa pelos críticos e a sua leitura foi considerada obrigatória pela Universidade Federal de Juiz de Fora (UFJF) na preparação para o vestibular. Publicou seis volumes: Baú de Ossos, Balão Cativo, Chão de Ferro, Beira-Mar, Galo das Trevas e Círio Perfeito, deixando incompleto o Cera das Almas, que será publicado em breve. Francisco de Assis Barbosa, da Academia Brasileira de Letras, disse em uma ocasião que a obra de Pedro Nava "é um desses monumentos que se levantam de cem em cem anos".

Em 1984, mais precisamente no dia 13 de maio, surpreendeu o País ao suicidar-se, o que foi um choque para os familiares e para a reumatologia brasileira. Tempos depois, soube-se que se tratava de depressão. Apesar desse gesto extremo, com certeza foi e ainda será um exemplo para os mais jovens, que, se não tiveram o prazer de conhecê-lo pessoalmente, têm agora a oportunidade de vislumbrá-lo em sua magnífica obra memorialística.

JOAQUIM JAGUARIBE NAVA RIBEIRO Médico reumatologista do HSE-RJ

Leia, a seguir, transcrição de dois artigos de Pedro Nava, publicados na Revista Brasil-Médico em agosto de 1959. 


\title{
Reumatismo Alergo Bacteriano(*)
}

\author{
"Don't think, try..." \\ HUNTER
}

Logo que principiamos a usar o ACTH e a cortisona, preocupou-nos de muito a propriedade que se lhes atribuía de poder fazer entrar em evolução os focos de tuberculose latente. Pensando nisso, nunca iniciamos uma terapêutica baseada nestes medicamentos sem um interrogatório que nos pudesse fazer afastar a idéia de tuberculização com lesão ativa anterior e, nos casos duvidosos, sem a realização de exames clínicos, radiológicos e laboratoriais que nos tirassem todas as dúvidas.

Foi dessa forma - e como mais uma garantia - que começamos a pedir o teste tuberculínico em nossos doentes. Não dávamos importância às reações de Mantoux positivas a 1/1.000 e emprestávamos valor relativo às respostas também positivas a 1/10.000. Certo dia o professor FERNANDO CARNEIRO chamou-nos a atenção para caso de paciente que examinara a nosso pedido e em quem as reações tinham assumido extraordinária intensidade à taxa de 1/ 10.000. Sugeriu esse Colega que, independente do tratamento anti-reumático, nossa paciente fizesse também a dessensibilização tuberculina que se impunha. Começou ela a se dessensibilizar. Com surpresa para mim e para o Professor FERNANDO CARNEIRO, seus fenômenos reumáticos que vinham resistindo duramente a toda terapêutica, foram declinando, para desaparecerem completamente, na medida em que progredia e se completava a dessensibilização.

Esse caso nos alertou e veio nos impor uma revisão quanto a reumatismo que olhávamos com o mesmo ceticismo que vem exarado em quase todos os livros: a doença de PONCET. Admitida por uns, negada pela maioria, essa entidade é, principalmente, afastada das cogitações reumatológicas - pelo modo errado por que se tem procurado conceituá-la.

PONCET, de Lyon - que primeiro a descreveu, considerava-a um reumatismo de origem tuberculosa, mas reumatismo sem germe local, capítulo dos fenômenos que ele reunia sob a designação de "tuberculose inflamatória”. Essa designação foi feita antes de serem descobertos e estudados os fenômenos alérgicos e só posteriormente é que MELCHIOR veio atribuir à doença de PONCET esse aspecto patogênico. Seu conceito legítimo deve ser o de um reumatismo alergo-tuberculoso.

A confusão e o negativismo existentes em torno dessa entidade resultaram dos exageros da própria Escola de Lyon quando atribuía também fundo tuberculoso ao reumatismo poliarticular agudo e à poliartrite crônica evolutiva (artrite reumatóide), além de não "tuberculose inflamatória" de PONCET, das atropatias tuberculosas com germe presente.

Até hoje, numerosos autores, sem negarem a existência do reumatismo de PONCET, pedem, para confirmação do seu diagnóstico, o achado do bacilo de $\mathrm{KOCH}$ por bacterioscopia, cultura ou inoculação - nos líquidos do derrame, nos triturados de tecidos articulares ou de gânglios satélites das juntas acometidas. Isso é um erro. Porque, achado o bacilo, o que há é artropatia tuberculosa, "abcesso frio", "tumor branco". Quanto ao reumatismo de PONCET, representa-se apenas pela fenomenologia alérgica.

Depois desse primeiro caso, resolvemos, em todos os reumatismos inflamatórios menos típicos, mesmo naqueles em que não íamos intentar a terapêutica pelo ACTH e pela cortisona, ver como se comportava o MANTOUX. E com freqüência esse teste passou a vir positivo, com reações intensas, ao título de 1/100.000. E mais ainda, como no primeiro caso, o tratamento dessensibilizante, sem outro auxílio - curava os fenômenos articulares.

Reunimos cerca de 20 casos desse gênero, com o professor FERNANDO CARNEIRO, os primeiros que observamos. Caracterizava-os o aspecto reumatóide das lesões, seu tipo inflamatório, a ausência de sinais radiológicos, a positividade do MANTOUX e a resposta terapêutica favorável à dessensibilização tuberculínica. Outra característica interessante destes pacientes - certo aspecto especial da pele das mãos: fria, úmida, congesta, vermelho-cianótica.

A admissão da existência real da doença de PONCET representou para nossa visão de reumatologista um passo de enorme importância. Além de termos adquirido novo instrumento de utilidade terapêutica específica para numerosos doentes, acostumamo-nos a separar da artrite

* Artigo publicado na Revista Brasil-Médico, n.os 31 a 50, 1 a 29 de agosto de 1959, págs. 457-9. 
reumatóide, não admitindo para eles esse diagnóstico um grande número de reumatismos de aspecto externo reumatóide, mas destituídos de substrato radiológico ósteo-articular.

Considerável progresso advir-nos-ia da ulterior observação de novos casos - ainda de aspecto externo reumatóide, sem lesões radiológicas osteoarticulares, mas agora sem o MANTOUX positivo a títulos apreciáveis. A conclusão lógica que se impunha, era uma aproximação analógica e a tentativa de demonstrar, nestes casos, a participação de outras alergias bacterianas além da tuberculosa. Com o auxílio dos Drs. E. BRUM NEGREIROS e ISAAC MALOGOLOVKIN, conseguem, finalmente, padronizar um sistema de pesquisa clínico-laboratorial que está nos permitindo agora - uma vez que a experiência terapêutica vem confirmando irrefutavelmente nossa hipótese inicial - admitir que as infecções agem no sentido reumato-artropático, seguindo dois caminhos.

Um, direto, com contaminação ou metástese articular, criação de artropatia purulenta e presença demonstrável de germe na junta. Essa eventualidade é rara: É a que todos os autores admitem sem discussão - baseados na confirmação anátomo-patológica e bacteriológica. Outro, indireto, alérgico, "poncetóide" - para usar a expressão feliz que para eles achou o Dr. E. BRUM NEGREIROS. Essa eventualidade é freqüente.

Estudando há anos o problema, temos atualmente para cima de 1.000 observações, onde, numa maioria esmagadora, a dessensibilização nos tem trazido os resultados mais favoráveis no dirimir o fenômeno reumático alergo-bacteriano. A dois grupos pertencem esses pacientes. Há um primeiro, onde o fenômeno alergo-bacteriano vem, constituindo ele só, todo o reumatismo. E há o segundo, onde ele incide sobre a osteoartrite ou sobre afecções para-reumáticas crônicas, criando então um tipo de reumatismo misto, associado. Essa incidência é tão freqüente que não hesitamos em considerá-la e denominá-la como a verdadeira "constante alergo-bacteriana", cujo papel étio-patogênico é tão intensivo como o dos outros elementos da constelação causal dos reumatismos crônicos, tais o trauma postural, as autointoxicações, etc., etc. É um fator que deve ser procurado sistematicamente e que é achado quase invariável nestas afecções. A determinação dessa constante alergo-bacteriana representa para nós índice de medidas curativas de incalculável valor.

Vamos precisar nossa conduta para chegar a essas indicações terapêuticas. Verificada uma síndrome reumática de aspecto externo inflamatório e destituído de substrato radiológico, examinamos todo o organismo para pesquisa de focos eventuais. Esses podem ser cutâneos, dentários, gengivais, amigdalianos, diverticuloso-esofagiano, vesiculares, apendiculares, intestinais, crípticos, sinusais, respiratórios, gênito-urinários e ganglionares. Talvez neste último grupo esteja a questão em aberto da tuberculização como infecção local. Estudamos os focos, passamos à outra parte do exame que se destina a nos dar informações - por si e por comparação - com o que a clínica mostrou. Essa segunda é a pesquisa das sensibilidades alergo-bacterianas: reação de MANTOUX e alergia microbiana para os germes dos grupos respiratório, intestinal e piogênico.

Durante essa testagem microbiana o paciente é acompanhado no sentido de lhes serem verificadas as reações gerais, locais e focais que sobrevenham, conforme o grupo pesquisado. A conclusão vai ser tirada da intensidade das mesmas e é a sua apreciação global que indica os germes que vamos juntar e qual a sua proporção na dessensibilização polivalente. A reação focal tem muito valor. Indica quase especificamente o foco responsável. Recentemente, e sob a influência do Dr. OLIVEIRA LIMA, o nosso assistente Dr. HILTON SEDA introduziu na pesquisa dos germes responsáveis pela sensibilização, um excelente melhoramento: separados os germes virulentos, esses são testados não mais por grupos, mas um a um por via muscular. Só entram na composição da vacina os que desencadeiam reação. Estamos assim, graças à modificação do Dr. HILTON SEDA, empregando vacinas mais eficazes.

Este é o estado atual de nossos conhecimentos sobre a forma reumática que chamamos de reumatismo alergo-bacteriano e sobre a complicação que designamos como a constante alergo-bacteriana dos reumatismos crônicos e das afecções para-reumáticas. A nossa experiência, como o dissemos, baseia-se atualmente em mais de 1.000 casos e estamos, a respeito, preparando memória a ser apresentada à Academia Nacional de Medicina. É com satisfação que verificamos o aparecimento na literatura européia, a partir de uns dois anos (nossa primeira referência ao assunto está no "BRASIL-MÉDICO”, n. ${ }^{\text {os }} 12$ e 13 de março de 1953, págs. 222 a 223), com o nome de "reumatismo inflamatório crônico curável do adulto", do mesmo reumatismo que já tinha separado, há muito, da artrite reumatóide. A observação estrangeira, sucedente à minha, mais me anima a chamar para o assunto a atenção imparcial dos colegas brasileiros. Para os que quiserem pensar dos reumatismos alergo-bacterianos o que eu antes pensava da doença de PONCET - só por pensar e antes de adquirir experiência! - é que lembro a frase de HUNTER, posta como epígrafe deste capítulo. 


\title{
Sobre o Possível Papel da Sensibilização por Produtos Tissulares Homólogos na Patogenia da Artrite Reumatóide
}

\author{
"Il vaut mieux se tromper hardiment \\ que de vivre dans l'hésitations" \\ AUVARD
}

Em 1951 apresentei ao II Congresso Europeu de Reumatologia nota prévia onde se continha hipótese sobre o obscuro problema da patogenia da artrite reumatóide. Parti do fato de as teorias que procuravam explicar a origem da artrite reumatóide por um simples fenômeno alérgico, pela ação direta de um germe ou de uma toxina sobre a articulação - serem insatisfatórias na demonstração do mecanismo patogênico dessa doença. Considerava, entretanto, possível concatenar fatos e opiniões permitindo a formulação de nova hipótese patogênica - levando em conta o papel da sensibilização e da hiper-reação do indivíduo a seus próprios produtos tissulares, explicando assim, de maneira mais razoável, o aparecimento e a evolução da artrite reumatóide, bem como conciliando as diversas teorias microbianas aventadas na sua gênese. Vejamos esses fatos e essas opiniões.

O primeiro é a constatação, através da observação clínica, do que TARNOPOLSKY chama de a "liberação etiológica" de um reumatismo. Esse autor dá tal nome ao fenômeno pelo qual uma artrite comprovadamente específica passa, a partir de certo momento, a não mais obedecer ao tratamento etiológico, assumindo caráter evolutivo crônico, devido ao que ele aponta como sendo a "potência artropática do terreno".

O segundo é a verificação de LANDOUZY e GOUGEROT, de que "quando uma articulação foi tomada de uma 'poussée' reumática, fica sensibilizada para a introdução, mesmo em proporções infinitesimais, do agente que lhe deu nascimento".

O terceiro está na lei de DUVERNEY, onde se diz que "por fim a realização do organismo e das articulações não é mais específica e produz-se não só mediante a introdução dos tóxicos que deram nascimento à artrite, como também à de qualquer outro tóxico".

O quarto está contido na essência do "fenômeno de BURKU". Esse experimentador provocou, em coelhos, reações de hipersensibilidade a frações homólogas a seus próprios tecidos, mediante a ação toxina estafilocócica ("By combining staphylococcus toxin with lens substance rabbits have been sensitized to lens and developed high precipitin titers for his substance" - "Staphylococcus toxin produced in rabbit muscle broth has sensitized the rabbit for the broth alone").

A liberação etiológica da TARNOPOLSKY; a sensibilização articular de LANDOUZY e GOUGEROT; a perda da especificidade de reação da junta segundo a lei de DUVERNEY; o fenômeno de BURKY - são fatos que o simples mecanismo infeccioso não pode explicar. Temos de apelar, no interpretá-los adequadamente, para outros processos imunológicos.

É o clássico, na explicação da patogenia da artrite reumatóide, o admitir-se que depois da sensibilização microbiana inicial, uma proteína heteróloga, um cristalóide e mesmo as influências do frio e do trauma possam ser agentes desencadeantes de novos surtos reumáticos.

Tendo em vista o que se disse anteriormente e o que demonstra principalmente o fenômeno de BURKY é que eu me permiti levantar a hipótese de que entre esses agentes desencadeantes, classicamente admitidos (proteína heteróloga, cristalóide, frio, trauma), venha figurar também uma fração homóloga do organismo doente. A reação a essa fração constituiria a doença. E essa fração teria adquirido capacidade desencadeante, por ação de um germe sempre dentro da ordem de idéias esplanada por BURKY.

A ser verdadeira essa hipótese, estariam conciliadas as várias teorias microbianas. Não um, mas vários germes poderiam figurar como fatores da ação sensibilizante de produtos oriundos dos próprios tecidos do doente. Até a ação do trauma poderia encontrar apoio no que também foi verificado por BURKY ("Such rabbits show an altered reactivity to trauma which may be due to animal's reaction to substances in the tissues which are liberated by the trauma and which are also contained in the broth to which the animal is reactive"). 
Resumindo, assim enuncio a minha hipótese: a artrite reumatóide seria inicialmente uma artropatia determinada por este ou aquele germe (estão aqui as artrites reumatóides que várias classificações admitem como de origem conhecida); esse germe tornaria sensibilizantes frações do próprio organismo agredido ("fenômeno de BURKY"); a reação a essas frações constituiria a doença já independente da causa etiológica ("liberação etiológica" e "potência artropática do terreno" de TARNOPOLSKY); as reinfecções, as condições pessoais, o frio, os traumas, manteriam a constância da reação à fração sensibilizante (aqui tem lugar toda a "constelação etiológica" da artrite reumatóide).

Apesar dessas idéias terem sido apresentadas como simples hipóteses de trabalho, isto é, como hipóteses a serem cientificamente confirmadas ou infirmadas em parte ou no todo, a atitude adotada pelos colegas brasileiros com relação a elas foi a do silêncio ou a da posição aprioristicamente contra. As transcrições na imprensa estrangeira, as referências que lhe fizeram MARIANO CASTEX ("Nueva contribucion al estudio de las reumatosis alergicas" in Prensa Médica Argentina, vol. XXXIX, n. $\left.{ }^{\circ} 28,1952\right)$ e HOBART REIMAN ("Infectious diseases. Eighteen annual review of significant publications" in Archives of Internal Medicine, vol. 91, n. $\left.{ }^{\circ} 3,1953\right)$, a retomada do assunto por TOUSSAINT e GAUDIN ("Autosensibilisation et polyarthrites chroniques" in Reumatismo, fascículo I, 1955), a multiplicação crescente da literatura sobre as doenças por auto-agressão, principalmente no terreno das colagenoses - mostram que minha hipótese não pode ser considerada como desarrazoada. Como especialista clínico, desafeito, portanto, às técnicas experimentais, não tinha possibilidade de comprovar minhas asserções e por isso apresentei-as ao Conselho Nacional de Pesquisas que, delas tomando conhecimento, votou uma bolsa para seu estudo - estudo este que foi entregue ao eminente Professor CARLOS CHAGAS. 